\title{
STEM (SCIENCE, TECHNOLOGY, ENGINEERING, AND MATHEMATICS) APPROACHES USING THEMATIC LEARNING MEDIA TO DEVELOP CRITICAL THINKING
}

\author{
Azka Falaih Rizqiyana ${ }^{1}$, Cris Ayu Setyaningsih ${ }^{2}$, Nurmita Sari ${ }^{3}$ \\ ${ }^{123}$ Universitas Muhammadiyah Pringsewu, Lampung, INDONESIA
}

Received 15 October 2020 - Revised 19 November 2020 - Accepted 09 March 2021

\begin{abstract}
Current learning emphasizes the integrationof science and technologyto face the challenges of the 21 st century. Elementary school students experience difficulties in developingcritical thinking skillsdue to the limitations of thematic learning media and appropriate learning approaches. Teachers must supportthe learning processfollowing the changing times, namelyintegrating Science, Technology, Engineering, and Mathematics (STEM) into fun learning. The purpose of this study was to determine the effectiveness of the approachstemusing thematic learningmediain developing the critical thinking skills of elementary school students. This research is a quantitative research using a quasi-experimentalmethod with one-group-pre-test-post-test, which is to seethe difference between the pre-test and post-test with 1 class without a control class. Furthermore, the data obtained in this study were in the form ofstudents 'answers to data collection instruments that measuredstudents' critical thinking skills before and after treatment with the approachSTEM using thematic learning media.Based on the results of data analysis and discussion,it is concluded that thecriteria for improvingstudents' critical thinking skills arein the moderate category, there is a difference in the meancritical thinkingskills between thepre-test group, namely before and the post-test group, namelyafter learning with theapproach STEM using thematic learning media and the post-test group, that is, after learning with the approach STEM using thematic learning media has average critical thinking skillsbetter than thepre-test group, namely before learning with the approach STEM using thematic learning media. Keywords: STEM, Learning Media, Thematic, Critical Thinking
\end{abstract}

\section{INTRODUCTION}

Current learning emphasizes the integration of science and technology to face the challenges of the 21st century. Therefore, teachers must prepare the next generation who have qualified human resources in the field of science and technology, so that learning is directed at the development of science and technology. The capability in science and engineering has also become the major focus of education studies in various countries because labor with this ability is needed [2].

Teachers must support the learning process following the changing times, namely integrating Science, Technology, Engineering, and Mathematics (STEM) into fun learning. STEM in learning is an approach that integrates several fields of science that are related to one another. Science requires mathematics as a tool in processing data, while technology and engineering are applications of science [1].

However, several international studies show that students' science and mathematics achievement, especially in developing countries, is still low. The results of the last Trends in International Mathematics and Science Study (TIMSS) which was held in 2015 for elementary school students showed that there were 16 out of 53 countries that obtained science achievement scores below the international average. Meanwhile, for mathematics achievement, there are 18 out of 54 countries with scores below the international average of 500 [8]. Not much different, the results

(c) 2021 by the authors; licensee PGSD UMP. This article is an open access article distributed under the terms and conditions of the Creative Commons Attribution License (http://creativecommons.org/licenses/by/4.0/). $\triangle$ azkafalaihr@umpri.acid (*Correspondence) 
of the Program for International Student Assessment the 2015(PISA) study on science achievement also showed that there were 40 out of 72 countries that had scores below the international average (493), while for mathematics achievement there were 36 out of 72 countries that has a score below the international average of 490 [14].

The achievements of Indonesian students in the fields of science and mathematics are also quite concerning. TIMSS 2015 shows that Indonesia is ranked 50th out of the total participating countries for both fields with an including TIMMS and PISA requires higher thinking skills (order HOTS), including critical thinking skills, while the current learning process still lingering on Lower Order Thinking Skills [15].

Thus teachers are required to make innovations in learning to improve student achievement through increasing critical thinking skills. Critical thinking is one of the skills necessary to deal with the industrial revolution 4.0, because critical thinking is done to answer the question of "how" and the "why" using the principles and concepts [3]. These thinking skills allow students to analyze and draw conclusions independently. If a person fails to think independently, he will imitate others, adopt beliefs, and accept other people's conclusions passively [5]. Therefore, these thinking skills must be taught and instilled from an early age, starting with basic education.

In this regard, learning media is needed that can attract students' attention and interest in learning because according to Piaget's theory of cognitive development, children at the age of primary school (7-11 years) are included in the concrete operational stage which requires the help of real objects to learn so that can interact directly with the environment as a learning experience [12]. Therefore, the use of media for elementary school students is very important and necessary in the learning process. The teacher as a facilitator has a role to provide thematic learning media under Permendikbud Number 65 of 2013 that learning atthe primary schoollevel accommodates integrated thematic learning.

STEM stands for Science Technology Engineering \& Mathematics. Kelley \& Knowles explains that STEM is an approach to teach two or more subjects STEM with authentic practice to increase student learning motivation [7]. Sanders also argues that STEM is a learning approach that explores two or more subjects STEM and one or more subjects in schools [9]. Learning with the approach STEM can train students to apply the knowledge learned in school with phenomena that occur in the real world [2]. As explained by the National Research Council, through learning STEM students have the opportunity to learn science, mathematics, and engineering by solving problems that have real-world applications [13].

Correlatedwith the development of science and technologyin elementary school students, learningmedia that canstimulate and attract students' interest are needed, namely thematic learning media for elementary school students. This is because learning in elementary schoolsin the 2013 curriculum uses integrated thematiclearning,which consists ofthemes and sub-themes which are an amalgamation of several subjects. Permendikbud Number 65 of 2013, it states that learning at the primary school level accommodates integratedthematic learning, integration across subjects, across aspects of learning, and cultural diversity. Thus the learning resources used by the teacher to facilitate learning must also be thematic.

Currently, learning activities that take place in elementary schools tend to focus on lower-order thinking [14], while education that is following future needs can only be realized if students can develophigher-order thinking skills. One ofthe things thatcause students to have low thinking skills isthat the learning process that has taken placeso far has not beenable to developthese thinking skills. Many components greatly influence the learning process in schools, including content standards and process standards. The learning process in schools is of course inseparable from content standards and educational process standards because both are used as teacher guidelines in implementing the learning process.

The existence of content standardsand the implementation ofappropriate process standardsin education units are expectedto improve the quality ofgraduateswhich in turncan improve the quality of education. Content standardscan be used as a referencein making learning media that can train students' thinking skills, while process standards are used as guidelines indesigning and implementinga series of learning activities, including determining a learning approach that suits student needs.

Oneof the important elements in the learning process is the learningmedia. Therefore,teachers are expected to be able to developteaching materials following school conditions, student backgrounds, and characteristics of the material to betaught. For example, in a theme that is related to science learning, a learning approach that is oftencarried out by teachersis teaching science conceptsin the form of a collection ofdefinitions or formulas. As a result, students tend to be less skilled in answering questions that are open and require higher-order thinking skills.

One of the efforts to overcome these difficulties is to develop a learning approach using appropriate learning media. If the learning material to be delivered is abstract, the learning media mustbe able to help studentsdescribe something abstract. Thus,it is necessary toresearch the learning approach STEM using thematic learning media in developing the critical thinking skills of elementary school students. 


\section{MATERIAL AND METHODS Methods}

This research conducted at SD Negeri 1 Sukoyoso Pringsewu. Research subjects were the fifth-grade students of SD Negeri 1 Sukoyoso Pringsewu, Lampung.This research is a quantitative studyusing a quasi-experimental method with a one-group-pre-test-post-test design, which sees the difference between the pre-test and post-test conducted in 1 class without a control class.

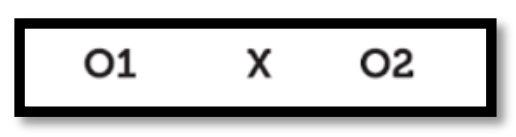

Figure 1. Design of Experimental Research

Description:

O1 = Pre-test

$\mathrm{X}=$ Treatment (Independent Variable)

$\mathrm{O} 2$ = Post-test [11]

In the current COVID19 pandemic situation, this research still uses offline learning. SD Negeri 1 Sukoyoso did not allow online learning to be held because not all parents can afford and have technology that supports online learning.

\section{Instrument}

The instrument used in this study was a test, consisting of a pre-test and a post-test. The pre-test instrument was intended to obtain preliminary data of students' ability before given treatment. Meanwhile, the post-test instrument was an instrument that was given after students received treatment. The test used was a written test in the form of multiple choices.

\section{Procedures}

The stages of this research consisting of:

1) The stage of preliminary study, this correlated to literature studies: Content Standards (KI, KD), Process Standards, Relevant research on the approach STEM and thematic learning media and critical thinking skills, Field studies: Learning approach, need for thematic learning media,critical thinking skills of students through observation andinterviews

2) The stage of Designing and manufacturing, namely designing learning procedures with STEM approach integrated with the preparation of learning tools, research instruments, and learning evaluation tools, designing instructional media designs thematic learning media used, Making thematic learning media according to the concept and design

3) The stage of implementation and publication, namely ComparingCritical Thinking Skillsbetween learning with the STEM approach using thematic learning media, Publications in accredited national journals, and producing in $\mathrm{m}$ a national seminar

\section{Data Analysis}

The test instrumentof critical thinkingability that was tried out consisted of 30 multiple choice questions with 4 alternative answer choices. The test instrument represents each indicator in theme 3 , namely figures and findings, sub-theme 1, namely the inventor who changed the world. The test trials were carried out in grade V at SD Negeri 1 Sukoyoso Pringsewu Lampung, which was given to 30 respondents. The test instrument was triedout to determine thecontentvalidity and reliability of thetest items.

The increasing score between pre-test and post-test show an increasing score in students' critical thinking skills. The increasing score was calculated based on the comparison gain of normalized or N-gain (g) using the Hake formula [4], namely: 


$$
<\text { g } \neq \frac{\%<\text { post-test }>-\%<\text { pre-test }>)}{(100-\%<\text { pre-test }>)}
$$

Description:

$<\mathrm{g}>\quad=$ average normalized gain = average $\mathrm{N}$-gain

$\%<$ post-test $>=$ post-test class percentage averages $=$ average post-test percentage

$\%<$ pre-test $>\quad=$ pre-test class percentage averages $=$ average percentage of pre-test

The N-gain criterion is "low" if $\leq 0.3$; "Medium" if N-gain $0.3<$ gain $\leq 0.7$; and "high" if the N-gain $>0.7$ [4].

Hypothesis testing was done by testing the similarity and difference between two means, previously a prerequisite test was conducted in the form of a normality test and a test for the similarity of two variances (homogeneity) of data.

\section{RESULTS AND DISCUSSION}

Pre-testand post-test weregiven to measure students' ability to think critically before and after learning using the STEM approach with thematic learning media. Before the instrument was distributed, it was first tested for content validity and reliability as follows.

Content validity includes aspects of construction and aspects of language. The content validity test was conducted by two validators, namely Yunni Arnida, M.Pd and Rahma Faelasofi, M.Sc, as lecturers in the PGSD study program. After the content validitytest was carried out by thevalidator, all items were declared valid because they met the criteria given. The predefined items were then tested for reliability. By using the KR-20 formula, the value of robtained $11=0.89$. Because $r 11=0.89>0.70$, the test instrument was said to be reliable.

The resultsof the pre-test and post-test were used asdatato test the effectiveness ofthis study. This valueis first tested for normality and homogeneity.

\section{a. Population Normality}

The normality test was carried out on each data population, the data on the critical thinking ability of the pretest and post-test students learning with the approach STEM using thematic learning media. The following is a summary of the data normality test for each population using the Liliefors Method with a significance level of 5\%.

Table. Summary of Data Normality Results of Students' Critical Thinking Ability Pre-test and Post-test with STEM Approach using Thematic Learning Media

\begin{tabular}{lrlll}
$\begin{array}{c}\text { Group of } \\
\text { Treatment }\end{array}$ & $\mathrm{L}_{\mathrm{obs}}$ & $\mathrm{L}_{(0,05 ; \mathrm{n})}$ & Test of Decision & Conclusion \\
\hline Pre-test & 0,1317 & 0,1730 & $\mathrm{H}_{0}$ accepted & Normally Distributed \\
\hline Post-test & 0,1515 & 0,1730 & $\mathrm{H}_{0}$ accepted & Normally Distributed \\
\hline
\end{tabular}

Based on the normality test summarized in the table above, it can be seen that Lobs for each population less than $\mathrm{L}(0,05 ; \mathrm{n})$, meaning that the critical area $\mathrm{DF}=\{\mathrm{L} \mid \mathrm{L}>\mathrm{L}(0,05 ; \mathrm{n}\}$ then Lobs DF. Thus it can be concluded that the samplesfrom the pre-testand post-test treatment groups camefrom populations that were normally distributed.

\section{b. Homogeneity Test of Population Variance The}

Homogeneity test aims to determine whether the population has the same variance. In the homogeneity test of the two groups, namely the pre-test group and the post-test group carried out learning with the approach STEM using thematic learning media used the F-test. Based on the results of the calculation of the homogeneity test of population variance obtained Fobs $=0,315$ and F0,05;24,24 $=1,98$. That is, with the critical area of DF $=\{F \mid F>$ F_((n_1-1,n_2-1) $\}=\{F \mid F>1,98\}$ then Fobs DF. Thus the decision of the test is H0 is accepted and concluded that the student population among the students in the group pre-test and post-test group performed learning approach STEM using thematic learning media has a homogeneous population variance.

c. Hypothesis Testing

1) Two-party t-test

The $t$-test is used to determine whether there is a difference in the average critical thinking skills of the pre-test group and the post-test group where learning is carried out using the approach STEM using thematic learning 
media. Based on the results of the two-party t-test calculation obtained tobs $=5,210$ and $t(0,025 ; 24)=2,064$, meaning that the critical area DF $=\{t \mid t>2,064\}$ then tobs $\in$ DF. Thus the test decision is H1 accepted and it is concluded that there is a difference in the mean critical thinking skills between the pre-test group and the posttest group where learning is carried out using the approach STEM using thematic learning media.

\section{2) one-party t-test}

The $t$-test is used to determine which group has better average critical thinking skills between the pre-test and post-test groups. Learning is done by the approach of STEM using thematic learning media. Based on the results of the one-party $t$-test calculation, it is obtained tobs $=5,210$ and $t(0,05 ; 24)=1.711$, meaning that with the critical area DF $=\{t \mid t>1,711\}$ then tobs $\in$ DF. Thus the test decision is $\mathrm{H} 1$ accepted and it is concluded that the post-test group carried out learning with the approach STEM using thematic learning media has an average critical thinking skill that is better than the pre-test group carried out learning with the approach STEM using thematic learning media

\section{DISCUSSION}

Based on data analysis carried out with one-party $t$-test, it was obtained tobs $=5,210$ and $t(0,05 ; 24)=1,711$, meaning that with the critical area DF $=\{t \mid t>1,711\}$ then tobs $\in$ DF.. Thus the test decision is H1 accepted and it is concluded that the post-test group carried out learning with the approach STEM using thematic learning media had an average critical thinking skill better than the pre-test group carried out learning with the approach STEM using thematic learning media. Then based on the $\mathrm{N}$-gain calculation, it was found that the $\mathrm{N}$-gain score was 0.4 so that it was included in the criteria for moderate improvement.

The increase in the average critical thinking skills of students is due to the STEM approach being able to challenge and motivate students in practicing critical thinking skills, analysis, and improving higher-order thinking skills. The STEM approach trains students to have a different way of thinking than usual and develop critical power in forming logical thinking, so this approach can be applied in various sciences. Besides, students will get used to solving problems well. STEM-based education will form human resources who are capable of reasoning and thinking critically, logically, and systematically. [6].

In connection with the development of science and technology in elementary school students, learning media that can stimulate and attract students' interest are needed, namely thematic learning media for elementary school students. This is because learning in elementary schools in the 2013 curriculum uses integrated thematic learning, which consists of themes and sub-themes which are an amalgamation of several subjects. Following Permendikbud Number 65 of 2013, it states that learning at the primary school level accommodates integrated thematic learning, integration across subjects, across aspects of learning, and cultural diversity.

For this reason, learningwith the approach ofSTEM using thematic learning mediamakes it easy for students to understand the concept ofa theme that does combine various interrelated subjects. Withthis understanding of the concept, students can analyze the problemsgiven by the teacher usingtheir thoughtsso that they can makechoices and draw conclusions intelligently. In this case, students' critical thinking skills improve.

The results of this study are in line with the research conducted byNovidya STEM (Science, Technology, Engineering, and Mathematics) learning for students can expand their knowledge to cover more concepts or/and science shortly, can improve student learning outcomes and responsive to solving problems requires a critical and effective way of thinking [9]. The learning process includesthe process of interpretation, analysis, evaluation, concluding, and explaining according to the realm of knowledge who can think critically. STEM learning that can be felt in real life, and can increase the logical logic of a problem. Then students can analyze events, data, and phenomena and relate to existing theories. After that, evaluate and concludewhat has been learned andconvey the information

\section{CONCLUSION}

Based on the results ofdata analysis and discussion,the following conclusionsare obtained. The criterion for improvingstudents' critical thinking skills is the medium category. There is a difference in the mean critical thinking skills between the pre-test group, namely before and the post-test group, namely after learning with the approach STEM using thematic learning media. The post-test group, that is, after learning with the approach stem using thematic learning media has an average critical thinking skill better than the pre-test group, namely before learning with the approach STEM using thematic learning media. 


\section{REFERENCES}

[1] Afriana, J., Permanasari, A., \& Fitriani, A. (2016). The application of Project Based Learning integrated STEM to increase science literacy students in terms of gender. Journal of Innovation in SCIENCE Education, 2(2), 202-212. https:/ / doi.org/10.21831/jipi.v2i2.8561

[2] Anggraini, F. I., \& Huzaifah, S. (2017). The implementation of STEM in SCIENCE learning in Secondary Schools. In the National Seminar on SCIENCE Education (Vol. 1, No. 1, pp. 722-731). http://conference.unsri.ac.id/index.php/semnasipa/article/view/738

[3] Cahyana, U., Kadir, A., \& Gherardini, M. (2017). The relationship of Critical Thinking Skills in the Literacy Skills of Science Students of Class IV Elementary School. Elementary school: the Study of the Theory and Practice of Education, 26(1), 14-22. http://dx.doi.org/10.17977/um009v26i12017p014

[4] Hake, R. R. (2002).Relationship of Individual Student Normalized Learning Gains in Mechanics with Gender, High-School Physics, and Pretest Scores on Mathematics and Spatial Visualization. Paper presented atthe Physics Education Research Conference. Boise, Idaho.

[5] Jonsons, E. B. (2002). Contextual Teaching and Learning, Make Learning Activities Fun and Meaningful. Kaifa Learning. Bandung.

[6] Kaniawati, D. S., Kaniawati, I., \& Suwarma, I. R. (2015). Literacy Study The Effect of Integrating the STEM Approach in the 5E Learning Cycle on Students' Problem Solving Ability in Learning Physics. Proceedings of the National Physics Seminar. FPMIPA UPI. Bandung

[7] Kelley, T. R., \& Knowles, J. G. (2016).A conceptual framework for integrated STEM education.International Journal of STEM Education, 3(1), 11. https:/ / doi.org/10.1186/s40594-016-0046-z

[8] Mullis, I.V.S. Martin, M.O., Foy, P., \& Hooper, M. (2017). TIMSS 2015 International Result in Mathematics.Association for the Evaluation of Educational Achievement (IEA) TIMSS \& pearls were the International Study Center, LynchSchool of Education, Boston College.

[9] Novidya, S D \& Kustijono, R. (2019). The effectiveness of the learning model STEM in order to increase students ' critical thinking skills. Proceedings of the National Seminar of $\begin{array}{lllll}\text { Physics } & \text { (SNF) } & \text { Unesa. } & \text { Vol } & 3,\end{array}$ https:/ fisika.fmipa.unesa.ac.id/proceedings/index.php/snf/article/view/108

[10] Sanders, M. (2009).STEM, STEM education, STEMmania. The Technology Teacher, 68(4), 20-26. http://hdl.handle.net/10919/51616

[11] Sugiyono. (2015).Methods of Educational Research: Quantitative Approach, Qualitative, and R \& D. Alfabeta. Bandung.

[12] Suyono \& Hariyanto. (2017). Learning and teaching: Theory and Basic Concepts. PT. Teen Rosdakarya. Bandung.

[13] The National Research Council. (2011). Successful K-12 STEM Education: Identifying Effective Approachesin Science, Technology, Engineering, and Mathematics. Washington, D.C:The National Academies Press.

[14] The Organisation for Economic Cooperation and Development(OECD). (2018). PISA 2015 Result in Focus. (Online). Available in (pisa-2015-results-in-focus.pdf, accessed on 20 June 2019).

[15] Widowati, Asri. (2009). The development of Critical Thinking Through the Application of the Model PBL (Problem Based Learning) in Science Learning. State University of Yogyakarta. Yogyakarta.

\section{http://jurnalnasional.ump/index.php/dinamika}

